\title{
Undermining democratic capacity: myth-making and oil development in Amazonian Ecuador
}

\author{
Susan Reider*, Robert Wasserstrom \\ Terra Group, 86 Cambridge Drive, Hershey, Pennsylvania 17033, USA
}

\begin{abstract}
Over the past $20 \mathrm{yr}$, a standard narrative has evolved to describe the impacts of oil development in Ecuador's Amazon region. According to this narrative, international oil companies exploited weak government oversight to destroy the rain forest and harm native communities. Eventually, Amazonian Indians and environmentalists joined together to fight 'big oil' in courts of law and public opinion. This story has been told in countless international campaigns, Internet posts, news and magazine articles, and even in a recent movie. Among North American and European academics, plaintiffs' lawyers, and journalists, it has now become almost a certainty. Yet many of its assumptions and implications remain unexamined. Are the essential facts true? Should private companies be held accountable for sovereign decisions made by government about oil development and indigenous rights? Why is this discourse so popular in the US, Canada, and Europe, but dismissed by many Ecuadorian social scientists? Using historical evidence and 3 case studies, we conclude that the standard narrative as it stands today obscures more than it explains and may undermine democratic governance in Ecuador.
\end{abstract}

KEY WORDS: Ecuador · Advocacy $\cdot$ Amazon $\cdot$ Oil $\cdot$ Tetete $\cdot$ Sansahuari Resale or republication not permitted without written consent of the publisher

\section{INTRODUCTION: FROM BANANA REPUBLIC TO PETROSTATE}

In 1967, Ecuador entered the world petroleum market when a significant oil discovery was made in the country's northeastern rain forest, known as the Oriente. Once again, Ecuadorians were faced with a question that had persisted since independence from Spain in 1822: how to incorporate the country's Amazonian territories. The oil boom, which began around Lago Agrio in 1972, seemed to provide a definitive answer (Schodt 1987, p. 107).

From 1972 to 1990, the Lago Agrio fields were operated by Texaco under a contract between the Ecuadorian government and the TexPet Consortium. TexPet originally included a third company, Gulf Oil, which sold its shares and left the country. By 1977 , the state oil company CEPE (later renamed Petroecuador) held $62.5 \%$ of the Consortium. Beginning in
1990, it replaced Texaco as the Consortium's operating partner, and in 1992, it assumed sole ownership of all production rights. In this paper, references to 'Texaco' will be reserved for actions involving the parent company, Texaco Corporation, which was acquired by Chevron in 2000.

Oil money allowed Ecuadorian officials to invest in education, health, and infrastructure projects, located primarily in Quito, Guayaquil, and other cities (Rodríguez Lara undated). Government payrolls swelled and a sizable middle class emerged (World Bank 1991, p. 1, Hurtado 1997, p. v-xxviii,). But petroleum production was also followed by massive borrowing against future revenues (Philip 1982, p. 115). Overcome by declining international prices, a growing national debt, and another border war with Peru, Ecuador's leaders regularly reduced gasoline subsidies and raised the price of public transportation (Martz 1987, p. 400-401). Street riots took 
place in Quito every year from 1981 to 1984. Increased petroleum production-even at lower world prices - seemed like the only solution.

In 1983, CEPE turned to foreign companies for new investment in unproven fields (Martz 1987, p. 354355). It awarded an exploration contract that included part of the Cuyabeno Wildlife Reserve to Occidental Petroleum Corporation (Oxy). Another contract was given to Conoco that included the Yasuní National Park (a UNESCO World Heritage Site and Biosphere Reserve, as well as traditional territory of the Huaorani people). Objections from environmental groups and indigenous rights advocates were ignored.

As roads extended throughout the northern Oriente, impoverished highland peasants flooded in and settled on 'unoccupied' land under Ecuador's agrarian reform laws (Baynard et al. 2013, Wasserstrom \& Southgate 2013). To secure their claims, migrants were required to cut down half the forest and plant pasture or other crops (Pichón 1993). Eager to expand the country's agricultural frontier, the government also provided low-interest loans and tax credits for large palm oil producers and cattle ranchers in the Amazon basin (Rudel 1993, p. 34). By 1994, when a new agrarian law (the Ley de Fomento Agropecuario) closed the Amazonian frontier, almost one-fifth of the country's eastern rain forest had been cleared for agriculture. Forced to compete with settlers for legal title to their own lands, the region's native people began to organize and resist (Vickers 1988). The Federation of Indigenous Organizations in Napo (FOIN) was founded in 1975, and the Organization of Indigenous Peoples of Pastaza (OPIP) was created in 1979.

\section{DEVELOPING THE STANDARD NARRATIVE}

Reaction against Conoco's presence in the Yasuní National Park began almost as soon as it announced its plans to explore for oil there in 1986. By 1989, a consortium of Ecuadorian and US environmental groups - notably, Rainforest Action Network (RAN), Natural Resources Defense Council (NRDC), Acción Ecológica (Ecological Action), the Sierra Club, and the Sierra Club Legal Defense Fund - launched the Amazon Campaign for Life (Hall 1993). In 1992, they were joined (albeit uneasily) by the country's 2 major indigenous political organizations, the Confederation of Indigenous Nationalities of Ecuador (CONAIE) and the Confederation of Indigenous Nationalities of the Ecuadorian Amazon (CONFENIAE; Hall 1993,
Sabin 1998, Kimerling 2006, p. 430). As the anti-oil campaign progressed, environmental activists also recruited non-Indian settlers to oppose petroleum policy (Sawyer 2001, p. 166).

Rather than pressure the Ecuadorian government, which owned the country's oil reserves and set land use policy, environmental groups instead opted to focus on foreign oil companies and international lenders (Treakle 2000, p. 225-226). A standard narrative began to emerge, emphasizing 4 basic messages: - Oil operations cause widespread deforestation and pollute the environment, especially rivers and streams.

- Petroleum companies usurp indigenous lands and disrupt traditional cultures.

- Oil development largely benefits foreign companies while Ecuadorians are stuck with the environmental and social costs.

- As agents of globalization and neoliberal penetration, private companies should bear the primary responsibility for these costs.

With slight variation, these messages were used over the next $15 \mathrm{yr}$ in campaigns targeting at least 8 international companies (see Appendix 1).

In some cases, the standard narrative went further: companies were accused of committing genocide against indigenous communities. This allegation was first made against Conoco in 1989, although it was quickly changed to 'ethnocide' (Hall 1993). In 1993, the charge was repeated in a lawsuit against Texaco and included the additional claim that oil companies pushed Indians off their land. According to one advocacy group, for example, 'Five indigenous groups in the region have lost $95 \%$ of their ancestral land and seen dramatic declines in their populations. These groups - the Cofan, Secoya, Siona, Kichwa, and Huaorani-had prospered in the rain forest for centuries before Texaco's arrival' (Amazon Defense Front 2009, p. 2-3). More recently, a third allegation was added: When Texaco arrived in 1964, advocates declared, 'two nomadic indigenous groups, the Tetetes and the Sansahuari, inhabited the region and were as of yet uncontacted by the outside world. Shortly after Texaco's arrival, they were reported to have disappeared forever' (Amazon Defense Front 2013, p. 1).

Since the 1980s, the standard narrative has evolved through trial and error. Its components were tested and refined in various campaigns - adding new elements and dropping the ones that failed to mobilize external support. Three case studies, based largely on our direct experience in Ecuador (1995-2013), illustrate how it has evolved. 


\section{Conoco, a doubtful victory}

In 1986, the North American company Conoco (at the time owned by chemical manufacturer DuPont), signed an agreement with the Ecuadorian government to explore Block 16. The block (200000 ha) included intact rain forest, as well as parts of the Yasuní National Park and ancestral homelands of the Huaorani people (also spelled Waorani). Almost immediately, RAN sent Conoco a warning letter about Block 16 and issued its first public 'action alert' in 1988. The following year, it launched a highvisibility campaign in the US, with support from key Ecuadorian environmental activists.

At first, RAN and its allies focused on protecting the region's flora and fauna against oil development. But they quickly realized that this approach had little resonance outside of forest preservation circles. Within a few months, they had expanded their campaign to cover another major component of the rain forest ecosystem: native people. The advantages of their new strategy soon became obvious. Indigenous people provided a bridge to the broader community of human rights activists, which attracted new supporters. A revised narrative was later articulated by Randy Hayes, RAN's executive director:

Unlike most of our U.S. forestlands, the tropical rain forest is inhabited. Their destruction not only raises questions of land rights and biodiversity - of monkeys, of trees. It also raises questions of people. The fate of the indigenous communities [is] deeply connected to the fate of the forest, raising profound human rights issues if their homelands are to be destroyed. If you destroy the forest, you destroy these people. In the rain forests, ecological and human rights issues are therefore deeply interlinked (quoted by Hall 1993, p. 6).

Problems arose immediately. Many indigenous groups did not want to be 'preserved.' Instead, they wanted the government to recognize their ancestral rights to the forest itself and share equitably in the benefits of development (Valerio Grefa, president of CONFENIAE as quoted by Hall 1993, Grefa 1993). They also wanted to participate 'in the design, execution and monitoring of [oil] projects in their territories' (Rafael Pandam, CONAIE vice president, quoted by CESR 1994, p. ix). Human rights activists who supported them were concerned about protecting indigenous lands, not about using Indian communities as props in a first-world environmental campaign.

In 1989, NRDC sent its own representative, Judith Kimerling, to Ecuador. In the Oriente, she led a team of lawyers and environmental specialists who inspected Texaco's former oil fields, which by then were operated by Petroecuador. Her 1991 book Amazon Crude, published by NRDC, revised the argument against oil development in Ecuador's rain forest. Until that time, environmental activism in Ecuador had focused mainly on deforestation. Kimerling (1991, p. 31) introduced a new element-pollution — into the campaign against oil:

Hundreds of oil wells generate more than 4.3 million gallons of toxic wastes every day, virtually all of which are spilled or discharged into the environment without treatment, contaminating countless streams and rivers often the only sources of water for surrounding communities. Burning oil and gas contaminate the air, along with volatile organics that enter the air from oil-covered waste pits and roads, and unremediated spills.

Faced with unrelenting international pressure, Conoco left Ecuador in 1991. Was this a victory for the forest? Robert Kennedy, Jr. (then head of NRDC's international program) offered his own judgment in the Washington Post:

American corporations with rain forest operations present an inviting target for U.S. environmental groups...But platitudes will not save the world's remaining rain forests. We need a more sophisticated approach, one that will allow us to negotiate with those corporations willing to commit themselves to the highest environmental standards. The problem, after all, is not caused by U.S. corporations, but by government decisions driven by a complex cycle of debt, poverty and growing populations (Kennedy 1992).

Ultimately, the anti-Conoco coalition fractured over indigenous rights and other differences. One faction opposed all development in the rain forest; another group indicated that it might reluctantly support development outside of the Yasuní National Park and Huaorani Territorial Reserve (Cummings 1993, Hall 1993, Fontaine 2003a, Fontaine \& Narváez 2007). Meanwhile, native groups often favored oil projects that brought significant benefits and included real safeguards (Sabin 1998). But Kennedy's objections to the standard narrativespecifically, to its exclusive focus on foreign companies, not Petroecuador or the Ecuadorian government - were ignored.

\section{The Texaco Campaign: Tetete and Sansahuari}

Even before Conoco departed in 1991, another element was added to the story: annihilation of an indigenous group called the Tetete. On 21 July 1987, the Ecuadorian media reported that Bishop Alejandro Labaca and Sister Inés Arango had been speared to death by Tagaeri, a Huaorani subgroup that had withdrawn from outside contact in 1968. Government 
reprisals against native people seemed like a real possibility. On July 24, CONFENIAE, the federation of Amazonian Indians, convened a press conference in Quito. Cabodevilla (1997, p. 16) wrote that 'In his statement to the press, [CONFENIAE's spokesman] lamented the missionaries' death, but they had been criminally used by economic interests that represent international oil, rubber and palm oil companies, which are undermining our lands to the point where only 2500 Huaorani survive of the 60000 who were living before oil development began...He added that 600000 Záparo and 30000 Tetete had been extinguished.'

CONFENIAE quickly abandoned this narrative and moved on to another position that emphasized its evolving vision of a more democratic, 'pluri-national' Ecuador. By 1991, it had also reduced its ties to antioil groups within the environmental movement (Hall 1993, Sawyer 1997, p. 71). Likewise, Ecuadorian anthropologists and historians largely ignored the Tetete legend: they saw it as an ill-conceived political gambit and apparently, they disagreed with it. Nevertheless, it has been kept alive by a small number of advocates in Ecuador and the US, who variously cite 'a 1987 government report' or 'a government official' as its source (CESR 1994, Kimerling 1994, p. 8, Switkes 1994, Jochnik 1995, Coffey et al. 1996, Little 1999, 2001). Although the 30000 figure is no longer mentioned, the legend of Tetete extermination has now found its way into the Texaco lawsuit in Ecuador (María Aguinda et al. V. Chevron) and into related commentary and media coverage.

The historical record tells a very different story (Wasserstrom et al. 2011). The Tetete were a small group related to nearby Siona-Secoya people; their territory lay within what later became the Cuyabeno Wildlife Reserve. From 1885 through the 1920s, Ecuadorian rubber collectors worked the area and shot or kidnapped Tetete people whenever they appeared. As Tetete numbers and territory shrank, their Siona neighbors expanded. Sometime before 1940, according to Siona oral tradition, a confrontation between Siona and Tetete people took place along the Aguarico River: 'The actual raid consisted of a typically Amazonian early morning sneak attack in which a number of Tetetes were reported to have been killed. The motive for the attack is said to have been a sorcery accusation that occurred...during a visit that the Tetetes made' to one Siona group living on the Aguarico River (Vickers 1983, p. 475).

In 1965 or 1966, a work crew cutting trails for oil exploration stumbled across several Tetete houses but saw no one. In March 1966, Capuchin missionar- ies found 2 old men and an old woman. Unfortunately, they had brought no translator, so they learned very little. In 1973, the same Tetete hamlet was visited by an American Protestant missionary, Orville Johnson, who brought 3 Siona-Secoya assistants. Johnson confirmed that the survivors represented a single, isolated household, but they refused to reveal much else. Talking to former enemies, they were understandably reluctant to admit that they were alone. After that, they were never seen again.

The truth about the Sansahuari is more startling: they never existed. An exhaustive search of missionary, anthropological, linguistic, and archival records finds no mention of any ethnic group called Sansahuari in the region. During the Rubber Boom (1885-1930), most of the area's inhabitants - Cofán and Siona people-moved to Capuchin missions along the Putumayo and San Miguel Rivers (today's international border between Colombia and Ecuador). In 1923, they fled the missions after a devastating measles epidemic and migrated into uninhabited areas farther downriver. In 1926, the missionaries found a small group of Cofán living near the Sansahuari River in Ecuador, where they collected rubber for sale to a Colombian merchant. A few years later, as the danger of epidemic faded, these Cofán moved back to their traditional homelands near the abandoned Capuchin missions, where they remain today. Until 2003, when the Texaco case was filed in Ecuador, no one had ever mentioned the Sansahuari. Apparently, they were invented to play the role of sympathetic victims.

Yet the story of their alleged disappearance at the hands of foreign oil men has taken on a life of its own. Consider these 3 examples. In 2003, when the Texaco lawsuit returned from New York to Ecuador, Acción Ecológica declared, 'Texaco is responsible for accelerating the extinction of indigenous peoples such as Tetetes and Sansahuari, who inhabited the area in where you [sic] installed the oil fields' (La Hora 2003, p. 3). In 2009, Kerry Kennedy, Robert Kennedy Jr.'s sister, wrote, 'The two nomadic groups that once inhabited the region, the Teteté and the Sansahuari, have been wiped out. What Texaco did arguably amounts to negligent homicide' (Kennedy 2009). More recently, plaintiffs' lawyer Pablo Fajardo claimed that 'The lands where Texaco started exploring back then were inhabited by native people like Siona, Secoya, Cofanes, Huaoranis, Tetete, Sansahuari-the latter two went extinct in the first years after Texaco got there' (Fajardo 2010). Similar claims have made their way into academic research (e.g. Martínez-Domínguez 2009). 


\section{Villano: building consensus, managing conflict}

By the late 1980s, native leaders began to fear that other parts of Ecuador's Amazon would be opened to oil development without their consultation or assent. Their fears were well-founded. In 1988, the Atlantic Richfield Corporation (ARCO) received oil exploration rights to Block 10 in Pastaza Province, south of TexPet's operations. In 1991, ARCO found significant oil deposits at a place called Villano, near a halfdozen small indigenous settlements. Soon, RAN began to circulate allegations of indigenous rights violations and environmental degradation (Mendez et al. 1998, Fontaine 2004).

In Villano, oil development created other tensions. Most of the province's native communities belonged to OPIP, which had been founded to defend native territories with help from the Catholic Church. Villano was an exception: it was affiliated with the Association of Indigenous Protestants in Pastaza, Amazon Region (AIEPRA), an evangelical organization that had split off from OPIP. During subsequent international campaigns against ARCO, OPIP and its allies claimed that the company used 'divide and conquer tactics' to hive Villano people off from OPIP (Brysk 2000, p. 171, Sawyer 2004, p. 4). But as anthropologist Haley (2004, p. 202) wrote, 'Prior to the services provided by ARCO, the communities had very little in the way of basic health, education, transportation, and communication services. It would have been very difficult for them to hold out and bargain for future, long-term sustainable benefits' including OPIP's vision of a single 'ethnic territory' in Pastaza (see Appendix 1).

Beginning in mid-1995, ARCO realized that it could expect no help from Petroecuador, which owned the Villano field. It invited OPIP, AIEPRA, and community members (who had formed their own Villano-based organization, the Association for the Indigenous Development of the Amazon Region, ASODIRA) to design a company-financed development plan. It hired an expert (the former head of FAO's Forest Trees and Peoples Program in Ecuador), who was acceptable to everyone. Honoring its earlier agreement with OPIP, it convened a 'Technical Environmental Committee' (CTA in Spanish) to oversee ARCO's activities with representatives from all 3 indigenous organizations. Over the next $3 \mathrm{yr}$, CTA members laid out a strategy for environmental monitoring and social investment in Pastaza. Villano communities participated directly in these discussions and approved the plan.
OPIP never completely renounced using the standard narrative as a tactical weapon against ARCO and the Ecuadorian government. Even as OPIP leaders participated in the CTA and worked with company representatives, they kept up international pressure for their broader political program via RAN in San Francisco, Oxfam America in Boston, and the Amazon Coalition in Washington. Although their objectives shifted, they ultimately demanded support from ARCO to wrest control over petroleum development in Pastaza from Petroecuador - a strategy that Petroecuador officials defeated by simply walking out of the room. Eventually, as Fontaine (2004) documented, OPIP leaders moved on to other issues, and ARCO's new owner, BP, sold its interest in Villano. However, the divide-and-conquer storyline struck a chord among foreign academics and activists, where it is still replayed.

In contrast, many observers in Ecuador took a positive view of ARCO's efforts. 'When all is said and done, Block 10 provided the stage for a series of experiments in building consensus on social and environmental issues arising from deficiencies in Ecuadorian policy. In this context, the sites of consultation that were constructed sui generis throughout the conflict (Technical Environmental Committee and Good Neighbor Forums) should be seen as efforts [by ARCO] to institutionalize relationships with indigenous organizations and communities' (Fontaine 2004, p. 31; see also Korovkin 2003). Caught in the cross currents between OPIP's political demands and government intransigence, other stakeholders nonetheless tried to find common ground. 'For us it has been a difficult process,' said one Villano leader, 'for the simple reason that there was no established procedure for working, negotiating and cooperating, neither for the company nor for the indigenous people' (Hector Mayancha, President of ASODIRA, quoted by Haley $2002^{1}$, p. 16).

In the end, Villano proved to be an unusual case. Ecuadorian authorities declined to copy it or institutionalize its lessons. Instead, Petroecuador maintained a long-standing policy, originally adopted in 1984, requiring private companies to 'meet the needs and social requirements of residents living in their areas of operation' as part of their operating contracts (Navarro 1995, p. 242). In Navarro's (1995, p. 243245) view, this policy has produced 'serious distortions' among indigenous communities:

\footnotetext{
1Haley S (2002) Communities and Corporations: "Leveraging Oil and Gas for Sustainable Local Development" (unpubl. manuscript)
} 
Hideous divisions have arisen among Amazonian groups, as companies have pursued their own strategies for meeting social needs. Bargaining and payments sowed the seeds of corruption, cultural disruption and, in synthesis, institutionalized anarchy... Meanwhile, communities and organizations have adopted a strategy of pressuring the companies to obtain financial aid or infrastructure that borders on blackmail.

Other experts have raised similar objections. According to Rodolfo Stavenhagen, the UN Special Rapporteur on the Situation of Human Rights and Fundamental Freedoms of Indigenous People, Ecuador's government continues to see itself as a broker between local communities and oil companies, rather than as a regulator or guarantor of human rights: 'With no State social policy, the local indigenous population must make do with the minimal social services provided by the oil companies, and they complain that their collective right to prior, free and informed consultation, as guaranteed in the Constitution, is not respected' (Stavenhagen 2006, p. 10). In particular, he notes 'the almost total lack of State institutions to protect and guarantee the rights of these indigenous people'. Despite the populist leanings of Ecuador's current president, Rafael Correa, this situation remains unchanged.

\section{TOO GOOD TO BE TRUE}

After the Conoco campaign, Acción Ecológica published a series of documents, articles and position papers arguing that oil production in Ecuador should be stopped completely or greatly curtailed (Garzón 1995, Martínez 1995, Coffey et al. 1996, Acosta et al. 2000). For the first time, they described the government as being 'merely an instrument' of international companies, which caused deforestation, pollution, and colonization (Varea \& Ortíz 1995, p. 100). Amplified by the Internet, their narrative spread through activist and academic networks in North America, Europe, and elsewhere. One prominent result of these efforts (Langewiesche 2007) appeared in the widely-circulated US magazine Vanity Fair:

But let's get the story straight. God created Earth, and later created oil, but until the 1950s he left Lago Agrio to its natural ways. Actually, Lago Agrio did not even exist in the 1950s. It did not have a name. It was an uncharted wilderness along the Aguarico River - a forest Eden roamed by small groups of naked Indians, some of whom believed that the only real world is the world of dreams. They hunted with blowguns, drank hallucinogenic brews, made love in the jungle, and sometimes shrank enemy heads.
This fanciful account reflects 2 enduring pillars of the standard narrative: the Oriente was a Garden of Eden before oil was discovered and native peoples flourished in isolation. It omits virtually all of the critical events that shaped indigenous life there: 4 centuries of Spanish domination and missionization; the Rubber Boom, when many of the area's Indians were enslaved by Ecuadorian and Colombian rubber tappers; the 1923 measles epidemic, which nearly wiped out most native communities; the Siona raid that ended Tetete history; the government's determination, in 1964 and 1972, to colonize indigenous lands; and government subsidies for commercial agriculture in the rain forest. And of course, it ignores the political decisions to spend oil money mostly in Quito and Guayaquil, where the votes are.

In contrast, social scientists in Ecuador have often looked beyond the behavior of individual foreign companies to explain the failures of oil development (Bustamante 2003, 2007, Fontaine 2003a, 2010; see also various contributors in Fontaine 2003b). They eschew the idea of 'state capture' by foreign operators; instead, they have tended to emphasize Ecuador's ongoing 'democratic deficiencies,' along with its populist politics, complex systems of rentseeking and corruption, ethnic and racial discrimination, and the persistent influence of political and economic elites. Problems like deforestation and loss of indigenous lands are framed as the outcomes of flawed governance and policy-making, not as the inevitable consequences of corporate misbehavior or international neoliberal machinations.

But the standard narrative is such a good storyone that fits an outsider's view of the Amazon - that it is too good to give up. It fuels advocacy campaigns, raises money, compels attention from celebrities, and generates periodic news coverage. It does not seem to matter that the narrative has been disavowed by the major researchers, human rights advocates, indigenous groups, and NGOs. Or that it simply is not true. As Fontaine and others have argued, international campaigns do a real disservice to Ecuador: they make the search for solutions harder and make these solutions harder to institutionalize. By radicalizing conflict, they deepen democratic deficiencies, instead of bridging them. They highlight failure, but attribute it to the wrong cause. According to Mainwaring (2008, p. 31), 'Effective state building must be at the core of the contemporary policy agenda... The critical need is to build a state that protects its citizens and guarantees their rights, that is efficient, and that interacts effectively with markets and with civil society to meet the challenges facing democracy in the twenty-first century.' 
In our view, the time has come to set aside the standard narrative in all of its variants. It does no service in strengthening government capacity or the rule of law. It has not helped to ensure indigenous territorial and cultural rights. It transposes cause and effect. It raises more questions than it answers-questions that lie at the heart of Ecuador's political mythology. How they are answered will ultimately determine whether its government will become more accountable to its citizens, whether it will develop its capacity to produce sustainable benefits for them. International researchers and activists can play an important role in achieving this outcome, but not if they continue to hold 'The Company' responsible for the government's failure to improve its own performance.

Acknowledgements. The authors thank 2 anonynmous reviewers for their extremely helpful comments.

\section{LITERATURE CITED}

Acosta A, Almeida A, Balseca M and others (2000) El Ecuador post petrolero. Acción Ecologica, Oilwatch, Ildis, Quito

Amazon Defense Front (2009) Understanding the lawsuit behind 'crude': background information on Aguinda v. ChevronTexaco. Available at www.chevrontoxico.com (accessed 12 November 2010)

Amazon Defense Front (2013) About the affected communities. Available at www.chevrontoxico.com/about/ affected-communities/about-the-affected-communities (accessed 22 June 2013)

Baynard C, Ellis J, Davis H (2013) Roads, petroleum and accessibility: the case of eastern Ecuador. GeoJournal 78: 675-695

Brysk A (2000) From tribal village to global village: Indian rights and international relations in Latin America. Stanford University Press, Palo Alto, CA

Bustamante T (2003) Las perspectivas de discusión de los temas socio-ambientales vinculados a la explotación petrolera en el Ecuador: posiciones encontradas o encuentro de posiciones. In: Fontaine G (ed) Petróleo y desarrollo sostenible en Ecuador. 1. Las reglas de juego. Facultad Latinoamericana de Ciencias Sociales (FLACSO), Quito, p 27-50

Bustamante T (2007) Detrás de la cortina de humo. FLACSO, Quito

Cabodevilla MA (1997) La selva de los fantasmas errantes. Centro de Investigaciones Culturales de la Amazonía Ecuatoriana (CICAME), Pompeya

CESR (The Center for Economic and Social Rights) (1994) Rights violations in the Ecuadorian Amazon. The human consequences of oil development. CESR, New York, NY.

Coffey G, Bravo E, Martínez E (1996) Oilwatch. Oilwatch, Quito

Cummings C (1993) Oil in the Ecuadorian rainforest: a primer. Management Institute for Environment and Business, New York, NY

Fajardo P (2010) Interview with Oscar Leon. Available at www.therealnews.com/t2/index.php?option=com_content
\&task=view\&id=31\&Itemid=74\&junival=6033 (accessed 13 January 2011)

Fontaine G (2003a) El precio del petróleo. FLACSO, Quito

Fontaine G (2003b) Petróleo y desarrollo sostenible en Ecuador. 1. Las reglas de juego. FLACSO, Quito

Fontaine G (2004) Análisis y evaluación de la gestión de los conflictos en el Bloque 10 (Ecuador). FLACSO, Quito

Fontaine G (2010) Petropolítica. Una teoría de la gobernanza energética. FLACSO, Quito

Fontaine G, Narváez I (2007) Yasuní en el siglo XXI. FLACSO, Quito

Garzón P (1995) Impacto socioambiental de la actividad petrolera: estudio de caso de las comunidades San Carlos y La Primavera. In: Varea A, Ortíz P (eds) Marea negra en la Amazonia. Ediciones Abya Yala, Quito, p 265-294

Grefa V (1993) Principales problemas de la región amazónica desde la perspectiva de la CONFENIAE. In: Ruíz L (ed) Amazonía. Escenarios y conflictos. CEDIME, Quito, p 413-420

$>$ Haley S (2004) Institutional assets for negotiating the terms of development: indigenous collective action and oil in Ecuador and Alaska. Econ Dev Cult Change 53:191-213

Hall S (1993) Block 16: Conoco's 'green' oil strategy. Harvard Business School Case N9-394-001. Harvard University, Cambridge, MA

Hurtado O (1997) El poder político en el Ecuador, 10th edn. Editorial Planeta, Quito

Jochnik C (1995) Texaco's devastating search for Amazon crude. Available at www.albionmonitor.com/11-14-195/ texacoamazon.html (accessed 4 April 2011)

Kennedy K (2009) Chevron and cultural genocide in Ecuador. www.huffingtonpost.com/kerry-kennedy/chevron-andcultural-geno_b_346257.html (accessed on 4 November 2009)

Kennedy R Jr (1992) Driving out Conoco disservice to rain forests. Washington Post, Washington, DC, (August 24, 1992), p A17

Kimerling J (1991) Amazon crude. Natural Resources Defense Council, New York, NY

Kimerling J (1994) Dislocation, evangelization, and contamination: Amazon crude and the Huaorani People. Woodrow Wilson Center, Washington, DC

Kimerling J (2006) Indigenous peoples and the oil frontier in Amazonia: the case of Ecuador, ChevronTexaco, and Aguinda v. Texaco. Int Law Polit 13:414-661

Korovkin T (2003) In search of dialogue: oil companies and indigenous peoples of the Ecuadorian Amazon. Can J Dev Stud 2:632-663

La Hora (2003) Presentan demanda contra la Texaco (6 May). Available at www.lahora.com.ec/index.php/noticias/show/ 1000160877/-1/Presentan_demanda_contra_la_Texaco. html (accessed on 17 March 2013)

Langewiesche W (2007) The next big environmental Davidand-Goliath trial. Vanity Fair, April 4, 2007. Available at http://amazonwatch.org/news/2007/0404-vanity-fair-thenext-big-environmental-david-and-goliath-trial (accessed on 13 April 2010)

Little P (1999) Political ecology as ethnography: the case of Ecuador's Aguarico River basin. Serie Antropológica 258. Instituto de Ciencias Sociales, Departamento de Antropología, Universidad de Brasilia, Brasilia

Little P (2001) Amazonia. Territorial struggles on perennial frontiers. Johns Hopkins, Baltimore, MD

Mainwaring S (2008) The crisis of representation in the Andes. In: Diamond L, Plattner M, Abente Brun, D (eds) 
Latin America's struggle for democracy. Johns Hopkins University Press, Baltimore, MD, p 18-32

Martínez E (1995) Rechazo a la Séptima Ronda de licitaciones petroleras. In: Varea A, Ortíz, P (eds) Marea negra en la Amazonia. Ediciones Abya Yala, Quito, p 181-218

Martínez-Domínguez M (2009) Oil politics in the Amazon: from ethnocide to resistance and survival. Soc Engagement Empowerment Change 11:1-12

Martz J (1987) Politics and petroleum in Ecuador. Transaction Books, New Brunswick, NJ

Mendez S, Parnell J, Wasserstrom R (1998) Seeking common ground. Petroleum and indigenous peoples in Ecuador's Amazon. Environment 40:12-45

Navarro M (1995) Conflictos en políticas de asignación y uso de los fondos de beneficio social y mitigación de impacto ambiental de las petroleras. In: Varea A, Ortíz P (eds) Marea negra en la Amazonia. Ediciones Abya Yala, Quito, p 241-264

Philip G (1982) Oil and politics in Latin America. Cambridge University Press, Cambridge

Pichón F (1993) Colonización y deforestación en la frontera agrícola de la región amazónica ecuatoriana. Resultados preliminares de una encuesta de hogares en el nor-oriente. In: Ruíz L (ed) Amazonia. Escenarios y conflictos. Centro para la Investigación y el Desarrollo de los Movimientos Sociales del Ecuador (CEDIME), Quito, p 337-374

Rudel T (1993) Tropical deforestation: small farmers and land clearing in the Ecuadorian Amazon. Columbia University Press, New York, NY

Sabin P (1998) Searching for middle ground: native communities and oil extraction in the northern and central Ecuadorian Amazon, 1967-1993. Environ Hist 3:144-168

Sawyer S (1997) The 1992 Indian mobilization in lowland Ecuador. Lat Am Perspect 24:65-82
Sawyer S (2001) Fictions of sovereignty: of prosthetic petrocapitalism, neoliberal states, and phantom-like citizens in Ecuador. J Lat Am Anthropol 6:156-197

Sawyer S (2004) Crude chronicles. Duke University Press, Durham, NC

Stavenhagen R (2006) Report of the Special Rapporteur on the situation of human rights and fundamental freedoms of Indigenous People. Mission to Ecuador. UN Human Rights Council A/HRC/4/32/Add.2.28. UN Human Rights Council, New York, NY

Switkes G (1994) The People vs. Texaco. NACLA Report on the Americas 28. North American Congress on Latin America, New York, NY

Treakle K (2000) Ecuador: structural adjustment and indigenous and environmentalist resistance. In: Fox, JA, Brown DL (eds) The struggle for accountability. MIT Press, Cambridge, MA, p 217-264

Varea A, Ortíz P (eds) (1995) Marea negra en la Amazonia. Ediciones Abya Yala, Quito

Vickers WT (1983) The territorial dimensions of Siona-Secoya and Encabellado adaptation. In: Hames, RD, Vickers, WT (eds) Adaptive responses of native Amazonians. Academic Press, New York, NY, p 451-478

Vickers WT (1988) Processes and problems of land demarcation for a native Amazonian community in Ecuador. Law Anthropol 3:204-245

> Wasserstrom R, Southgate D (2013) Deforestation, agrarian reform and oil development in Ecuador, 1964-1994. Nat Resour 4:31-44

> Wasserstrom R, Reider S, Lara R (2011) Nobody knew their names: the legend of Tetete extermination. Ethnohistory 58:421-443

World Bank (1991) Ecuador. Public sector reforms for growth in the era of declining oil output. World Bank, Washington, DC 
Appendix 1. Milestones in government policy, indigenous resistance and environmental activism in Ecuador, 1964-2011

Year Event

1964 Government opens 'vacant' areas in Oriente to outside settlers. Indigenous communities are also allowed to receive 'unclaimed' or under-utilized land formerly owned by private haciendas.

Federación Shuar is founded in southern Oriente to defend traditional territory from highland migrants.

1967 TexPet announces a major petroleum discovery in Napo Province.

1972 TexPet begins production at its Lago Agrio and Shushufindi fields.

ECUARUNARI is founded in highland Ecuador to seek land titles and political rights for Quichua communities.

1974 Revised Agrarian Reform Law effectively requires homesteaders to clear $50 \%$ of their land before receiving permanent title.

1975 Federation of Indigenous Organizations in Napo (FOIN) is founded to defend indigenous land rights in Napo Province.

1978 Government adopts 'Amazon Region Settlement Act,' declaring most of Oriente to be public land and encouraging highland dwellers to resettle there.

Illiterates (mostly indigenous people) are allowed to vote for the first time.

1979 Organization of Indigenous Peoples of Pastaza (OPIP) formed in Pastaza Province.

1980 FOIN, OPIP, and the Federación Shuar form CONFENIAE, Confederation of Indigenous Nationalities of the Ecuadorian Amazon.

1984 Government leases Block 15, including part of the Cuyabeno Wildlife Reserve, to Occidental Petroleum Company.

1986 CONFENIAE and ECUARUNARI form Confederation of Indigenous Nationalities of Ecuador (CONAIE). Within 10 yr, CONAIE becomes the country's major national indigenous political organization.

Acción Ecológica is founded to oppose oil development in Ecuador's rain forests.

Conoco signs exploration agreement for Block 16, including part of Yasuní National Park.

1988 International advocacy campaign against Conoco begins.

US-based Atlantic Richfield Corporation (ARCO) receives exploration rights in Block 10 in Pastaza Province.

OPIP forms 'base group' in Block 10, also known as Villano.

1989 First international campaign against Texaco begins.

ARCO's seismic contractor and Petroecuador employees 'kidnapped' by native activists at Sarayacu.

1990 International campaign against ARCO begins.

CONAIE organizes the first 'National Indian Uprising' protesting against government failure to respect indigenous rights.

Huaorani Reserve designated.

1991 Conoco leaves Ecuador. Petroecuador transfers Block 16 to US company Maxus, which builds an access road into the block. (In 1995 Maxus is bought by the Spanish firm Repsol.)

1992 International campaign against Maxus begins in Block 16.

OPIP organizes a protest march from the Amazon to Quito demanding formation of a 'plurinational territory' in Pastaza Province. This territory would include a grant of land to OPIP alone.

Non-indigenous settlers in Pastaza, who would presumably lose their own land rights, strike against OPIP's demand for a plurinational territory. The government subsequently issues 19 communal land titles to indigenous communities. OPIP is infuriated.

ARCO announces a significant oil discovery at Villano.

1993 A lawsuit against Texaco is filed in US District Court in New York on behalf of Napo residents.

Communities near Villano form their own organization (eventually named the Association for Indigenous Development, Amazon Region, ASODIRA) to negotiate with ARCO for community benefits. OPIP accuses ARCO of adopting 'divide and conquer' tactics.

1994 OPIP, CONFENIAE, and CONAIE occupy the Ministry of Energy and Mines in Quito to protest against their exclusion from discussions of Ecuador's development and from the 7th Petroleum Bid Round, which opens new rainforest areas for oil exploration. CONAIE organizes 'Mobilization for Life' to protest against a new Agricultural Development Law that transfers communally held land to individual property owners. It also demands a moratorium on oil development in the Amazon.

1996 Eight indigenous representatives of a new CONAIE-sponsored political party, Pachakutik, are elected to the Ecuadorian Congress.

1997 International campaign against Occidental begins.

1998 Ecuador adopts a new constitution requiring 'prior consultation' of indigenous communities before resource development begins and a share of benefits from it.

2000 International campaign against Burlington begins. International campaign against EnCana begins.

President Jamil Mahuad deposed by a triumvirate, including Antonio Vargas, head of CONAIE.

2001 International campaign against OCP (Heavy Oil Pipeline) Consortium begins.

2003 Amazon Defense Front (ADF, a coalition of environmental advocacy groups) renews earlier calls to suspend future oil development. ADF (also called Amazon Defense Coalition) plays a prominent role in publicizing claims made by plaintiffs in the Texaco case.

The Texaco lawsuit is dismissed by US courts; a new suit is filed in Ecuador.

2006 Canadian oil company EnCana sells its Ecuadorian operations to a joint venture of Chinese companies.

2010 President Rafael Corerra proposes his 'Yasuní Initiative,' whereby wealthy nations would pay Ecuador to forego oil production within the Yasuni National Park and adjacent areas.

2011 The Ecuadorian court finds Texaco guilty of pollution for its Lago Agrio and Shushufindi operations; it imposes a fine of US\$18 billion (subsequently raised to $\$ 19.6$ billion). 